African Crop Science Journal by African Crop Science Society is licensed under a Creative Commons Attribution 3.0 Uganda License. Based on a work at www.ajol.info/ and www.bioline.org.br/cs DOI: http://dx.doi.org/10.4314/acsj.v25i1.1S

\title{
DETERMINANTS OF ADOPTION OF IMPROVED MAIZE VARIETIES IN KANO-KATSINA-MARADI, WEST AFRICA
}

\author{
I. ADEDIPE OLUWAYEMISI, L.O. OLARINDE ${ }^{1}$ and A.O. FATUNBI ${ }^{2}$ \\ Ultimate AgResearch Ltd, 31 Gwaranduk Road, Off Namua Junction, Abattoir, Jos, Plateau State, Nigeria \\ ${ }^{1}$ Agricultural Economist-Department of Agricultural Economics, Ladoke Akintola University of Technology \\ P.M.B. 4000, Ogbomoso 210001, Oyo State, Nigeria \\ ${ }^{2}$ Forum for Agricultural Research in Africa (FARA),12 Anmeda Street, Roman Ridge PMB CT 173, \\ Cantonments, Accra, Ghana \\ Corresponding author: yemesee@yahoo.co.uk
}

\begin{abstract}
The introduction of improved maize (Zea mays L.) varieties has met with only partial success, as measured by rates of adoption. As such, efforts have been made by International Institute of Tropical Agriculture (IITA) to accelerate the process of maize seed adoption in Africa, through learning sites including the Kano-Katsina-Maradi (KKM PLS) in West Africa. The objective of this study was to ascertain the degree of success and factors affecting the adoption of improved maize seed varieties in the KKM PLS. The study used data from a midline survey sample of 1,800 households in 180 villages in the study area. Tobit regression model was used to identify the degree and characteristics important for adoption of improved maize seed varieties. Results indicated that affordability, knowledge on use and suitable packaging of technology were important adoption determinants. Other factors were gender, total farm size and extension agent visits. Households with older and more educated heads were also significantly more likely to adopt technologies.
\end{abstract}

Key Words: IITA, learning sites, Zea mays

\section{RÉSUMÉ}

L'introduction des variétés améliorées de maïs (Zea mays L.) a connu de succès partiel, comme indiquée par les taux d'adoption. Ainsi, des efforts ont été menés par l'Institut International d'Agriculture Tropicale (IITA) pour accelérer les processus d'adoption des semences de maïs en Africa, à travers les sites d'apprentissage y compris le Kano-Katsina-Maradi (KKM PLS) en Afrique de l'Ouest. L'objectif de cette étude était de s'assurer du degré du succès et les facteurs affectant l'adoption des semences de variétes améliorées de maïs en KKM PLS. L'étude a utilisé les données d'un échantillon d'enquête basée sur une ligne médiane de 1800 ménages en 180 villages dans le milieu d'étude. Le model de régression de Tobi était utlisé pour identifier le degré et les caractéristiques importantes pour l'adoption des semences de variétés améliorées de maïs. Les résultats ont montrré que l' accessibilité, la connaissance sur l'usage et un paquet technologique adéquat étaient les plus importants déterminants d'adoption. Les autres facteurs étaient le genre, la superficie totale du champ et les visites des agents de vulgarisation. Les ménages avec des personnes plus agées et plus instruites ont significativement plus de chance d'adopter les technologies.

Mots Clés: IITA, sites d'apprentissage, Zea mays 


\section{INTRODUCTION}

Increasing agricultural productivity in Nigeria is of urgent necessity, for instance through the introduction and use of improved seed varieties. Agricultural productivity and, hence, production using improved seed varieties has been identified as a precondition for achieving food security (Langyintuo et al., 2000; Bernard et al., 2010). Seed is recognised to have the greatest ability of increasing on-farm productivity, since seed determines the upper limit of crop yields and the productivity of all other agricultural inputs (MoA, 2004; Bernard et al., 2010). This means that, to increase as well as sustain production volumes, it will be critical to find mechanisms that guarantee farmers access to improved and high yielding seed varieties.

The global maize production trend shows that although 68 percent of the global maize area is in the, developing world, only 46 percent of the world's maize production is grown there (Pingali and Pandey, 2001). Low average yields in the developing world are responsible for this wide gap between global share of area and share of production. The average maize yield in developed countries is 8 metric tonnes per hectare; while that of developing countries is below 3 metric tonnes per hectare. Disparities in climatic conditions, as well as farming technologies, account for the 5 metric tonnes per hectare yield differential between developed and developing world. The unmet need for improved maize seed is met by recycling grain as seed. According to Pixley and Banziger (2001), when farmers recycle grain they are faced by risk of declined yields of between 5 percent for open pollinated varieties (OPV) and 30 percent for hybrids.

One of the agencies that has risen to the challenge of low agricultural productivity resulting from several constraints, including limited adoption of improved seed varieties, is the Forum for Agricultural Research in Africa (FARA). As a follow up to this, the SubSaharan Africa Challenge Programme (SSA
CP), through its implementer, the Forum for Agricultural Research in Africa (FARA) used the Innovation Platform (IP) system of the Integrated Agricultural Research for Development (IAR4D) to advocate for the sustainable use of improved seed variety to address the challenge of limited adoption of improved seed varieties, and thereby ensuring sustainable agricultural productivity. The SSA$\mathrm{CP}$ was implemented in three Pilot Learning Sites (PLS) which are Lake Kivu (LK) in Eastern and Southern Africa, Kano-KatsinaMaradi (KKM) in West Africa, and ZimbabweMalawi-Mozambique (ZMM) in Southern Africa. The KKM PLS is located on the border between south central Niger and North central Nigeria, and encompasses three different agroecological zones (AEZs) that cross all of West and Central Africa at this latitude: (i) The Sahel Savanna (SaS); (ii) The Sudan Savanna (SS); and (iii) The Northern Guinea Savanna (NGS). These are referred to as the Taskforces (TF).

This study was carried out to ascertain the degree of adoption and factors affecting the adoption of improved maize seed varieties in the KKM PLS in West Africa.

\section{METHODOLOGY}

Summary statistic and classical hypothesis group mean was used to analyse the difference in the means of farm and farmer's characteristics of non-adopters and adopters. The Tobit regression model was employed to analyse the degree of adoption of improved maize seed varieties. In assessing the degree of adoption, specific improved varieties were not considered rather, all improved maize seed varieties were addressed as one. It was also employed to analyse the degree of improved maize seed varieties adoption across 4 regions (KKM PLS, NGS, SaS and SS).

The Tobit adoption model. The Tobit model, developed by Tobin (1958), assumes that a farm household's decision to adopt a given technology, $\mathrm{Y}_{\mathrm{i}}$, in a given period is presumed 
to be derived from the maximisation of expected utility (increased yield and income). However, the utility derivable from any new technology, depends on a vector of explanatory variables, $\mathrm{Xi}$. Thus, the probability that a household will adopt a new technology with an increased yield or income objective is a function of the vector of explanatory variables, $\mathrm{Xi}$, the unknown parameters, $\beta \mathrm{i}$, and the error term, $\mu_{i}$, assumed to be independently $N\left(0, \sigma^{2}\right)$ distributed, conditional on the $\mathrm{X}_{\mathrm{i}}$ 's. This is expressed as:

$\mathrm{Y}^{*}=\mathrm{X} \beta+\mu_{\mathrm{i}}$ Equation 1

Where:

$\mathrm{Y}^{*}$ is a latent variable (the expected utility) that is unobservable.

If data for the dependent variable is above the limiting factor, zero in this case, $\mathrm{Y}_{\mathrm{i}}$ is the dependent variable which is observed as a continuous variable (e.g. proportion of land area cultivated to crop varieties by the ith household). If $Y_{i}$ is at the limiting factor, it is held at zero. This relationship is presented mathematically in the following two equations:

$\mathrm{Y}_{\mathrm{i}}=\mathrm{Y}_{\mathrm{i}}^{*}$ if $\mathrm{Y}_{\mathrm{i}}^{*}>\mathrm{Y}_{\mathrm{i}} ; \mathrm{Y}_{\mathrm{i}}=0$ if $\mathrm{Y}_{\mathrm{i}}^{*}<\mathrm{Y}_{\mathrm{i}}$ Equation 2

Where:

$\mathrm{Y}_{\mathrm{i}}$ is the limiting factor

These two equations represent a censored distribution of the data. The Tobit model can be used to estimate the expected value of $Y_{i}$ as a function of a set of explanatory variables $\left(X_{i}\right)$, which represents households' socioeconomic-, technology-, and institutional related factors, weighted by the probability that $\mathrm{Y}_{\mathrm{i}}>0$. Since the disturbance term, $\mathrm{m}_{\mathrm{i}}$, is a function of the independent variables, an attempt to estimate Equation 2 using Ordinary Least Squares will result in biased and inconsistent estimates (Maddala, 1983;
Gujarati, 2006). The use of maximum likelihood estimation guarantees that the parameter estimates will be asymptotically efficient for the appropriate statistical tests to be performed (Pindyck and Rubinfeld, 1997). Maddala (1983) shows that the expected intensity of adoption, $\mathrm{E}(\mathrm{Y})$, is:

$\mathrm{E}(\mathrm{Y})=\mathrm{X} \beta \mathrm{F}(\mathrm{z})+\sigma \mathrm{f}(\mathrm{z})$ and $\mathrm{z}=\mathrm{X} \beta / \sigma$ Equation 3

Where:

$\mathrm{F}(\mathrm{z})=$ the cumulative normal distribution of $\mathrm{z}, \mathrm{f}(\mathrm{z})=$ the value of the derivative of the normal curve at a given point (unit normal density), $\mathrm{z}=$ the $\mathrm{Z}$-score for the area under the normal curve, and $\mathrm{s}=$ the standard error of the error term.

The coefficients for variables in the model, b, do not represent marginal effects directly, but the sign of the coefficient will give information as to the direction of the effect.

Study area, data collection. The SSA CP was being implemented in three PLS across the continent. The Kano, Katsina and Maradi (KKM) PLS covered 83,900 $\mathrm{Km}^{2}$ and straddled Nigeria and Niger, covering an area, which is home to about 18.3 million people. The KKM pilot learning site was located on the border between south central Niger and North central Nigeria, and encompassed three different agroecological zones (AEZs) that cross all of West and Central Africa at this latitude: (i) The Sahel Savanna (Sahel); (ii) The Sudan Savanna (SS); and (iii) The Northern Guinea Savanna (NGS). As one moves from the northern to the southern parts of this PLS, average temperatures decline, and annual rainfall and the length of the growing period increase. Principal crops in the PLS included: (i) cereals (pearl millet, sorghum, maize, upland rice, and wheat), (ii) legumes (groundnut, cowpea, soybeans), (iii) roots and tubers (cassava, sweet potato); and (iv) cotton. Other emerging crops include tiger nuts (Cyperus esculentus) 
and sesame (Sesamum indicum). Vegetable crops (pepper, onion, tomatoes, cabbage or water melon) are mainly grown under irrigation. In all three agro ecological zones, livestock is an essential part of the production systems.

The survey for this study was conducted by taskforces within the framework of the Sub-Saharan African Challenge Programme. The sample frame was derived from different districts, selected to represent the three basic areas of taskforces in the KKM PLS. In each district, a sample of households was selected by taking a sample of district wards; a random sample of villages within each ward; and a random sample of households in each selected village. Finally, a household was retained in the sample if it belonged to one of the 180 villages selected within the clean, conventional or IP/action sites.

The midline survey was conducted in 2010/ 2011, covered a total of 1800 households from 180 villages in 3 Task Forces (TFs), which are NGS, SaS and SS. Multistage stratified random sampling procedures (earlier at the inception of implementation of the SSA CP) were applied and carried out in the three TFs, within the previously selected districts (IAR4D and counterfactual to select the villages, where the treatment was applied, that is villages where IAR4D are introduced, village/communities where conventional approaches were in operation, and villages where no interventions had been carried out over the last 2-5 years.

The variables included in the analysis included socioeconomic and demographic variables such as age, gender, educational level, household size, extension visits (dummy and actual), farming experience, use of improved technologies, and extension agencies, and research institutions.

\section{RESULTS AND DISCUSSION}

Specific characteristics of farmers were closely related to the adoption of improved maize seed varieties compared across two strata of farmers-adopted and non-adopted on a PLS level and TFs levels (Table 1). The proportion of adopters was more likely to be educated, have access to credit assistance and the differences were statistically significant. This suggests a correlation between the adoption of improved maize varieties and both farmers' level of education and access to credit. Adopters had significantly higher years of independent household farming compare to Non adopters. Probably, their years of experience influenced their adoption decision. They also have larger household size suggesting that family labour availability is a determinant of the decision to adopt improved maize varieties. The finding is also consisted with observation reported by Mendola (2006), implying that the subsistence pressure exerted on a household (consumption needs resulting from having more family members) might be a determinant of the choice to adopt improved varieties.

The age of household members in active age group (16 to 58) and below this age group who adopted improved varieties is significantly different between adopters and non-adopters, with adopters reporting higher. This has a positive bearing on their ability to accept maize varieties, tendency of being highly productive and quite independent. Age of an individual affects his mental attitude to new ideas and may influence his decision in several ways. Younger farmers have been found to be more knowledgeable about new practices and may be more willing to bear risk and adopt a technology because of their longer planning horizons (Polson and Spencer, 1991).

Adopter were also more likely to be married, with the household heads being male, with more household members above the age of 59, to have been visited more by agricultural extension agents in the past 12 months and to have also visited agricultural extension agents/ service more number of times for advice in the past 12 months.

Characteristics of the Northern Guinea Savanna Taskforce (NGS TF) are presented 
TABLE 1. Household and farm characteristics of the Kano-Katsina-Maradi Pilot Learning Site in West Africa

Characteristics $\quad \frac{\text { Means }}{$\cline { 3 - 4 }}

\section{Household and farm characteristics}

Age of household head in years

Number of males aged 16 to 58 years

Number of females aged 16 to 58 years

Number of members aged below 16 years

Number of members aged 59 and above in years

Household size (number)

Number of years of independent household farming

Total farm size (ha)

Size of land under maize cultivation (ha)

Number of times visits to agricultural extension agent/service for

advice in the past 12 months

Number of visited by agricultural extension agent/in the past 12 months

Proportion of household head gender ${ }^{\dagger}$

Proportion of household head house hold level of education ${ }^{\dagger}$

Proportion of marital status ${ }^{\dagger}$

Proportion of membership of group ${ }^{\dagger}$

Proportion of visited agricultural extension agent/service for advice in

the past 12 months ${ }^{\dagger}$

Proportion of visited by agricultural extension agent/in the past 12 months ${ }^{\dagger}$

Proportion of participated in agricultural research or extension

demonstration ${ }^{\dagger}$

Proportion of access to credit $\dagger^{\dagger}$

Proportion of access to assistance ${ }^{\dagger}$

$\begin{array}{rrc}49.60 & 50.88 & -1.28 * * \\ 3.12 & 3.89 & -0.77 * * * \\ 3.10 & 3.47 & -0.37 * * \\ 5.55 & 6.45 & -0.90^{* * *} \\ 0.59 & 0.63 & -0.04 \\ 12.43 & 14.58 & -2.15 * * * \\ 26.31 & 28.22 & -1.91 * * * \\ 5.25 & 5.23 & 0.02 \\ 2.29 & 2.21 & 0.08 \\ 1.24 & 1.42 & -0.18 \\ & & \\ 1.60 & 1.51 & 0.09 \\ 0.96 & 0.97 & -0.01 \\ 0.16 & 0.21 & -0.05 * * \\ 0.91 & 0.92 & -0.01 \\ 0.26 & 0.24 & 0.01 \\ 0.27 & 0.29 & 0.02 \\ & & \\ 0.30 & 0.32 & -0.02 \\ 0.21 & 0.20 & 0.01 \\ & & \\ 0.59 & 0.54 & 0.05 * * \\ 0.32 & 0.38 & -0.06 * * * \\ & & \end{array}$

Unequal-variance t tests: $*=\operatorname{Sig}$ at $10 \% ; * *=\operatorname{Sig}$ at $5 \% ; * * *=\operatorname{Sig}$ at $1 \% ;{ }^{\dagger}=$ dummy variable

in Table 2. There is significant difference in the proportion of married adopters and nonadopters, with the married Adopters ranking higher. It is expected that family labour would be more available where farmers were married, and this also determines the household size. Adopters were also more likely to be male headed, educated, members of a group, with more total farm size and also cultivated maize on larger farm lands.

The average number of visits made to agricultural extension agents/service was statistically different between adopters (1.17) and non-adopters (0.76). Likewise, the average number visit made by agricultural extension agent to household was statistically different between adopters (1.36) and non-adopters
(0.76). Farmers must have information about the intrinsic characteristics of improved varieties before they can consider planting them. Contact with extension agents exposes farmers to information on new ideas and technologies, during the year on the importance and application of new innovations through demonstrations (Herath and Takeya, 2003). It can, therefore, stimulate adoption (Polson and Spencer, 1991).

Table 3 presents characteristics of the Sahel Savanna Taskforce (SaS TF), where the proportion of adopters was more likely to be educated and to have participated in agricultural research or extension demonstration. Statistically, adopters were likely to have had an average of 1.27 and 0.24 number of visit 
TABLE 2. Household and farm characteristics of the Northern Guinea Savanna Taskforce (NGSTF)

\begin{tabular}{|c|c|c|c|}
\hline \multirow[t]{2}{*}{ Characteristics } & \multicolumn{3}{|c|}{ Means } \\
\hline & Non adopter & Adopter & Difference \\
\hline \multicolumn{4}{|l|}{ Household and farm characteristics } \\
\hline Age of household head in years & 52.31 & 51.62 & 0.69 \\
\hline Number of males aged 16 to 58 years & 4.21 & 4.36 & -0.15 \\
\hline Number of females aged 16 to 58 years & 3.90 & 3.87 & 0.03 \\
\hline Number of members aged below 16 years & 6.20 & 6.76 & -0.56 \\
\hline Number of members aged 59 and above in years & 0.74 & 0.68 & 0.05 \\
\hline Household size (number) & 15.40 & 15.99 & -0.59 \\
\hline Number of years of independent household farming & 29.51 & 28.98 & 0.52 \\
\hline Total farm size (ha) & 4.88 & 5.40 & -0.52 \\
\hline Size of land under maize cultivation (ha) & 2.09 & 2.32 & -0.23 \\
\hline $\begin{array}{l}\text { Number of visits to agricultural extension agent/service for advice in } \\
\text { the past } 12 \text { months }\end{array}$ & 0.76 & 1.17 & $-0.42 * *$ \\
\hline $\begin{array}{l}\text { Number of times visited by agricultural extension agent/in the past } \\
12 \text { months }\end{array}$ & 0.76 & 1.36 & $-0.65 * * *$ \\
\hline Proportion of household head gender ${ }^{\dagger}$ & 0.99 & 1.00 & -0.01 \\
\hline Proportion of household head house hold level of education ${ }^{\dagger}$ & 0.21 & 0.25 & -0.05 \\
\hline Proportion of marital status ${ }^{\dagger}$ & 0.88 & 0.93 & $-0.05^{* *}$ \\
\hline Proportion of membership of group ${ }^{\dagger}$ & 0.11 & 0.13 & -0.02 \\
\hline $\begin{array}{l}\text { Proportion of visited agricultural extension agent/service for advice in } \\
\text { the past } 12 \text { months }\end{array}$ & 0.21 & 0.19 & 0.02 \\
\hline Proportion of visited by agricultural extension agent/in the past 12 months ${ }^{\dagger}$ & 0.30 & 0.25 & 0.05 \\
\hline $\begin{array}{l}\text { Proportion of participated in agricultural research or extension } \\
\text { demonstration }{ }^{\dagger}\end{array}$ & 0.11 & 0.09 & 0.02 \\
\hline Proportion of access to credit $\dagger^{\dagger}$ & 0.51 & 0.49 & 0.01 \\
\hline Proportion of access to assistance ${ }^{\dagger}$ & 0.35 & 0.36 & 0.00 \\
\hline
\end{tabular}

Unequal-variance $t$ tests: $*=\operatorname{Sig}$ at $10 \% ; * *=\operatorname{Sig}$ at $5 \% ; * * *=\operatorname{Sig}$ at $1 \% ;{ }^{\dagger}=$ dummy variable

to agricultural extension agents/services and number of visits by agricultural extension agent in the past 12 months. Access to extension or training is typically thought to reduce the risk of accepting improved maize varieties. Adopters had significant access to assistance compared to the non-adopters $(0.27$ and 0.21 , respectively). This suggests a correlation between farmers 'decision to adopt improved maize varieties and the level of assistance they receive.

The average household size, years of independent household farming, household members below 16 years and age of household head were not statistically significant; but likely to be more than those of non-adopters. Table 4 presents characteristics of the Sudan
Savanna Taskforce (SS TF), where the proportion of adopters were more likely to be married, be member of a group, had ever participated in agricultural research or extension demonstration and also visited agricultural extension agent/service in the past 12 months for. The number of adopter's times of visit to agricultural extension agent/service in the past 12 months for advice, and number of times being visited by agricultural extension agent in the past 12 months, were also likely to be more, but without statistically significant difference. However, the proportion of agricultural extension agent visit in the past 12 months to the adopter and the adopter's access to assistance (0.51 and 0.49) were likely to be significantly more than the non- 
TABLE 3. Household and farm characteristics of the SAHEL Taskforce (STF)

\begin{tabular}{|c|c|c|c|}
\hline \multirow[t]{2}{*}{ Characteristics } & \multicolumn{3}{|c|}{ Means } \\
\hline & Non adopter & Adopter & Difference \\
\hline \multicolumn{4}{|l|}{ Household and farm characteristics } \\
\hline Age of household head in years & 48.84 & 49.06 & -0.23 \\
\hline Number of males aged 16 to 58 years & 2.49 & 2.43 & 0.06 \\
\hline Number of females aged 16 to 58 years & 2.67 & 2.64 & 0.03 \\
\hline Number of members aged below 16 years & 5.40 & 5.64 & -0.24 \\
\hline Number of members aged 59 and above in years & 0.74 & 0.69 & 0.05 \\
\hline Household size (number) & 11.29 & 11.40 & -0.11 \\
\hline Number of years of independent household farming & 25.69 & 26.50 & -0.82 \\
\hline Total farm size (ha) & 5.50 & 5.34 & 0.11 \\
\hline Size of land under maize cultivation (ha) & 2.41 & 2.17 & 0.24 \\
\hline $\begin{array}{l}\text { Number of visits to } 12 \text { months extension agent/service for advice in } \\
\text { the past } 12 \text { months }\end{array}$ & 0.66 & 1.27 & $-0.61 * *$ \\
\hline $\begin{array}{l}\text { Number of times visited by agricultural extension agent/in the past } \\
12 \text { months }\end{array}$ & 1.03 & 1.19 & -0.16 \\
\hline Proportion of household head gender ${ }^{\dagger}$ & 0.90 & 0.88 & 0.03 \\
\hline Proportion of household head house hold level of education ${ }^{\dagger}$ & 0.05 & 0.08 & -0.03 \\
\hline Proportion of marital status ${ }^{\dagger}$ & 0.89 & 0.86 & 0.03 \\
\hline Proportion of membership of group ${ }^{\dagger}$ & 0.19 & 0.17 & 0.02 \\
\hline $\begin{array}{l}\text { Proportion of visited agricultural extension agent/service for advice in } \\
\text { the past } 12 \text { months }\end{array}$ & 0.18 & 0.24 & $-0.06^{*}$ \\
\hline Proportion of visited by agricultural extension agent/in the past 12 months ${ }^{\dagger}$ & 0.18 & 0.21 & -0.02 \\
\hline $\begin{array}{l}\text { Proportion of participated in agricultural research or extension } \\
\text { demonstration }\end{array}$ & 0.20 & 0.20 & -0.01 \\
\hline Proportion of access to credit $\dagger^{\dagger}$ & 0.67 & 0.64 & 0.03 \\
\hline Proportion of access to assistance ${ }^{\dagger}$ & 0.21 & 0.27 & $-0.06^{*}$ \\
\hline
\end{tabular}

Unequal-variance $t$ tests: $*=\operatorname{Sig}$ at $10 \% ; * *=\operatorname{Sig}$ at $5 \% ; * * *=\operatorname{Sig}$ at $1 \% ;{ }^{\dagger}=$ dummy variable

adopters (0.44 and 0.42), respectively. This suggests that there is a correlation between farmers' adoption decision and extension visit and this is also true about access to assistance. Likewise, the average household size, years of independent household farming, age of household head, number of males aged 16 to 58 years, number of females aged 16 to 58 years, number of members aged below 16 years and number of members aged above 59 years of adopters are $(15.24,28.54,51.30$, $4.40,3.58,6.68$ and 0.52 ), respectively compared to non-adopters $(11.87,24.97$, $48.73,3.13,3.06,5.31$ and 0.33 ), respectively.

The household size revealed the availability of labour. This has a positive effect on farm production, the total area cultivated to different crop enterprises, the amount of farm produce retained for domestic consumption and marketable surplus. Franzel's (1999) study on the adoption of improved tree fallows also found that labour constraints had a significant impact on the adoption decision.

The mean years of independent farming experience showed that farmers were quite experienced and should be able to make adoption decision. The basic assumption is that familiarity decreases the uncertainty of accepting improved seed varieties. Experience is also gained by trialing a new technology, especially in the instance of new crop varieties.

Farmer's adoption and degree of adoption. Table 5 summarises the maximum likelihood 
TABLE 4. Household and farm characteristics of the Sudan Savanna Taskforce (SSTF)

\begin{tabular}{|c|c|c|c|}
\hline \multirow[t]{2}{*}{ Characteristics } & \multicolumn{3}{|c|}{ Means } \\
\hline & on adopter & Adopter & Difference \\
\hline \multicolumn{4}{|l|}{ Household and farm characteristics } \\
\hline Age of household head in years & 48.73 & 51.30 & $-2.58 * *$ \\
\hline Number of males aged 16 to 58 years & 3.13 & 4.40 & $-1.27 * * *$ \\
\hline Number of females aged 16 to 58 years & 3.06 & 3.58 & $-0.52 *$ \\
\hline Number of members aged below 16 years & 5.31 & 6.68 & $-1.37 * * *$ \\
\hline Number of members aged 59 and above in years & 0.33 & 0.52 & $-0.19 * * *$ \\
\hline Household size (number) & 11.87 & 15.24 & $-3.36 * * *$ \\
\hline Number of years of independent household farming & 24.97 & 28.54 & $-3.57 * * *$ \\
\hline Total farm size (ha) & 5.20 & 4.89 & 0.32 \\
\hline Size of land under maize cultivation (ha) & 2.27 & 2.01 & 0.17 \\
\hline $\begin{array}{l}\text { Number of visits to agricultural extension agent/service for advice in the past } \\
12 \text { months }\end{array}$ & 1.94 & 2.39 & -0.45 \\
\hline Number of times visited by agricultural extension agent/in the past 12 months & hs 2.39 & 2.78 & -0.40 \\
\hline Proportion of household head gender ${ }^{\dagger}$ & 1.00 & 0.99 & 0.01 \\
\hline Proportion of household head house hold level of education ${ }^{\dagger}$ & 0.26 & 0.25 & 0.02 \\
\hline Proportion of marital status ${ }^{\dagger}$ & 0.94 & 0.95 & -0.01 \\
\hline Proportion of membership of group & 0.43 & 0.45 & -0.02 \\
\hline $\begin{array}{l}\text { Proportion of visited agricultural extension agent/service for advice in } \\
\text { the past } 12 \text { months }\end{array}$ & 0.41 & 0.47 & -0.05 \\
\hline Proportion of visited by agricultural extension agent/in the past 12 months ${ }^{\dagger}$ & 0.44 & 0.51 & $-0.08^{*}$ \\
\hline $\begin{array}{l}\text { Proportion of participated in agricultural research or extension } \\
\text { demonstration }\end{array}$ & 0.29 & 0.34 & -0.05 \\
\hline Proportion of access to credit $\dagger^{\dagger}$ & 0.56 & 0.52 & 0.04 \\
\hline Proportion of access to assistance ${ }^{\dagger}$ & 0.42 & 0.49 & $-0.07 *$ \\
\hline
\end{tabular}

Unequal-variance $t$ tests: $*=\operatorname{Sig}$ at $10 \% ; * *=\operatorname{Sig}$ at $5 \% ; * * *=\operatorname{Sig}$ at $1 \% ;{ }^{\dagger}=$ dummy variable

estimates for the Tobit model for improved maize seed varieties across the KKM PLS and the 3 TFs. The level of education of respondents was significant at $10 \%$ for the KKM PLS and at 5\% for the SS TF in influencing the degree of adoption.

At both the KKM PLS level and the SaS TF, the gender result was statistically significant. The gender of the household head matters in explaining adoption of improved maize seed varieties, with adoption favoring male-headed households. This is quite understandable given the fact that the farming communities were of Islamic faith, in which direct involvement of women in farming activity is prohibited. More women at the time of this project were willing to participate in this project, but were deprived by their husbands that could not entrust their wives in the hands of male extension agents. For most technologies, a larger proportion of males correspond with a higher chance of adoption. Evidence suggests that female-headed households are less likely to adopt technologies than male-headed households (Doss and Morris, 2001).

The decision-maker's perception about the new varieties' yield potentials are also important factors in determining degree of improved maize seed varieties' adoption. The degree of adoption for the NGS TF was significantly but inversely influenced by age of household head at $5 \%$ and his participation in research or extension demonstration was also influenced at $10 \%$. The degree of adoption due to the fact that improved seed varieties were very 
TABLE 5. Determinants of farmer's adoption and degree of adoption of improved maize seed varieties in West Africa

\begin{tabular}{|c|c|c|c|c|}
\hline Variable description & KKM & NGS & SAHEL & SS \\
\hline Gender of household head ${ }^{\dagger}$ & $0.62 * * *$ & -0.31 & $0.89 * * *$ & 0.89 \\
\hline Age of household head in years & 0.00 & $-0.02 *$ & -0.01 & 0.01 \\
\hline Marital status ${ }^{\dagger}$ & -0.22 & -0.29 & -0.30 & 0.32 \\
\hline Education level of household head ${ }^{\dagger}$ & $0.20 *$ & 0.01 & 0.25 & $0.41 * *$ \\
\hline Number of males aged 16 to 58 years & 0.01 & 0.01 & 0.08 & 0.00 \\
\hline Number of females aged 16 to 58 years & -0.01 & -0.02 & -0.02 & 0.00 \\
\hline Number of members aged below 16 years & 0.00 & 0.03 & 0.00 & -0.02 \\
\hline Number of members aged 59 and above in years & 0.01 & 0.02 & 0.04 & 0.08 \\
\hline Household size & 0.00 & 0.00 & 0.00 & 0.00 \\
\hline Number of years of independent household farming & 0.01 & 0.01 & 0.01 & -0.01 \\
\hline Total farm size (ha) & $0.39 * * *$ & $0.40^{* * *}$ & $0.40^{* * *}$ & * $0.37 * * *$ \\
\hline Membership of group & -0.02 & -0.19 & 0.12 & 0.00 \\
\hline $\begin{array}{l}\text { Visited agricultural extension agent/service for advice in the past } \\
12 \text { months }\end{array}$ & -0.09 & -0.21 & 0.04 & 0.16 \\
\hline $\begin{array}{l}\text { Number of visits to agricultural extension agent/service for } \\
\text { advice in the past } 12 \text { months }\end{array}$ & 0.00 & -0.02 & -0.05 & 0.03 \\
\hline Visited by agricultural extension agent/in the past 12 months $^{\dagger}$ & -0.03 & 0.28 & -0.29 & 0.01 \\
\hline $\begin{array}{l}\text { Number of visited by agricultural extension agent/in the } \\
\text { past } 12 \text { months }\end{array}$ & -0.01 & $-0.15^{* *}$ & 0.04 & 0.00 \\
\hline Participated in agricultural research or extension demonstration & 0.02 & 0.06 & 0.31 & -0.12 \\
\hline Access to credit ${ }^{\dagger}$ & 0.05 & 0.18 & 0.18 & -0.09 \\
\hline Access to assistance ${ }^{\dagger}$ & 0.09 & 0.16 & -0.16 & -0.12 \\
\hline Distance from house to regular source & 0.00 & 0.00 & 0.00 & 0.01 \\
\hline Time taken in hours to get to regular source & -0.01 & 0.00 & -0.03 & -0.03 \\
\hline Improved seed very affordable & $0.41 *$ & $0.84 * *$ & $0.81 *$ & 0.04 \\
\hline Improved seed affordable & 0.13 & 0.48 & 0.56 & -0.40 \\
\hline Improved seed not affordable & 0.18 & 0.16 & $0.87 * *$ & -0.13 \\
\hline Source too far from home & 0.12 & 0.18 & 0.39 & -0.12 \\
\hline Improved seed not in suitable packaging & $0.48 * *$ & 0.50 & $0.93 * * *$ & 0.32 \\
\hline No knowledge on how to use improved seed varieties & $0.48 * * *$ & $0.53^{*}$ & $0.65 *$ & $0.61 * *$ \\
\hline No to transportation to source of improved seed varieties & 0.28 & 0.23 & $0.84 *$ & 0.17 \\
\hline Lack of enough money & 0.14 & 0.30 & -0.11 & $0.38^{*}$ \\
\hline Constant & -0.60 & 0.44 & $-1.48 * *$ & -1.13 \\
\hline Number of obs & 618 & 207 & 202 & 209 \\
\hline $\operatorname{LR}_{\operatorname{chi}^{2}}(28)$ & 748 & 293.82 & 263.61 & 246.95 \\
\hline Prob $>\mathrm{Chi}^{2}$ & 0 & 0 & 0 & 0 \\
\hline Pseudo $\mathrm{R}^{2}$ & 0.2911 & 0.3299 & 0.303 & 0.3114 \\
\hline Log likelihood & -910.82 & -298.43 & -303.14 & 273.00 \\
\hline
\end{tabular}

Unequal-variance $t$ tests: $*=\operatorname{Sig}$ at $10 \% ; * *=\operatorname{Sig}$ at $5 \% ; * * *=$ Sig at $1 \% ;{ }^{\dagger}=$ dummy variable

affordable, was also significant at $1 \%, 5 \%$ and $1 \%$ for the KKM PLS, NGS TF and the Sahel TF levels, respectively.

Farm size was significant $10 \%$ across the 4 regions in influencing the adoption of improved maize variety. The positive sign of the coefficient of farm size implied that as the sizes of farmland increased, the farmers used more of the improved maize variety. $48 \%$ of KKM and $93 \%$ of NGS farmers perceived that the degree of adoption was negatively affected by improved seed not in suitable packages 
while $48 \%, 53 \%, 65 \%$ and $61 \%$ of KKM, NGS, Sahel and SS perceived lack of knowledge on how to use it negatively affected it. Information sharing is critical to adoption especially of improved maize seed varieties. When a farmer is not informed on how to use a technology, he may scarcely adopt it. $38 \%$ of farmers in the SS TF perceived lack of enough money also had its negative effects on this improved maize varieties adoption. This is not unexpected because adopters of improved maize varieties would incur more cost in production of improved maize seed varieties and will therefore need more money than non-adopters.

\section{CONCLUSION}

This study indicates that the affordability, knowledge on use and suitable packaging of improved maize seed varieties are important determinants of adoption of improved maize seed varieties The farmer and farm characteristics that significantly influence varietal adoption decisions include the status of being male-headed, total farm size and number of visits by extension agent. Households with educated heads and age of household head are also significantly more likely to adopt improved varieties. The empirical results of this study are useful in the design of policy strategies or interventions that will assist in increasing the adoption and utilisation of improved technologies such as drought tolerant maize seed varieties among smallholder farmers. Adoption of these improved maize technologies will help to increase agricultural productivity and hence improve food security in KKM PLS, hence, in the Sub Saharan Africa. For instance, the positive interaction between knowledge on the use of improved maize seed varieties and the adoption of technologies suggests that farmers have to be thought and trained on how to make use of improved technologies. More so the number of visits by extension agents to farmers also positively interacted with adoption, intervention strategies should be designed and implemented to encourage households with low levels of formal education to often be visited by extension agents for their positive impact on information diffusion and technology adoption. Affordability of improved maize seed varieties also positively interacted with the adoption of improved maize seed varieties and this also suggests that efforts should be made to reduce the cost of purchasing this technology or alternatively, assist farmers in accessing credit for purchase.

\section{REFERENCES}

Bernard, M., Jon, H., Rose, N. and John, M. 2010. Determinants for use of certified maize seed and the relative importance of transaction costs: Contributed Paper presented at the Joint 3rd African Association of Agricultural Economists (AAAE) and 48th Agricultural Economists Association of South Africa (AEASA) Conference, Cape Town, South Africa, September 19-23, 2010.

Doss, C.R. and Morris, M.L. 2001. How does gender affect the adoption of agricultural innovations? The case of improved maize technology in Ghana. Agricultural Economics 25: 27-39.

Doss, C.R., Wilfred, M., Hugo, V. and de G. Hugo. 2003. Adoption of maize and wheat technologies in East Africa: Synthesis of the findings of 22 case studies, Mexico, D.F. CIMMYT. http://www.cimmyt.org/ english/docs /eco wpaper/ewp03-06.pdf

Franzel, S. 1999. Socioeconomic factors affecting the adoption potential of improved tree fallows in Africa. Agroforestry Systems 47: 305-321.

Gujarati, D.N. 2006. Basic econometrics, $4^{\text {th }}$ Edition, Tata McGraw-Hill Publishing Company Limited, New York, USA.

Herath, P.H.M.U. and Takeya, H. 2003. Factors determining intercropping by rubber smallholders in SriLanka: A Logit 
Analysis. Agricultural Economics 29(3):159-168.

Mendola M. 2006. Agricultural technology adoption and poverty reduction: A propensity-score matching analysis for rural Bangladesh. Food Policy 32: 372393.

Pindyck, R.S and Rubinfeld, D.L. 1997 Econometric Models and Economic Forecasts, (Fourth edition), McGraw-Hill. London, UK.

Pingali, P.L. and Pandey, S. 2001. Meeting world maize needs: Technological opportunities and priorities for the public sector. CIMMYT. Mexico, D.F.

Pixley, K. and Banziger, M. 2001. Openpollinated maize varieties: A backward step or a valuable option for farmers. In: Seventh Eastern and Southern African Maize Conference. Harare, Zimbabwe. pp. 22-28. https://www.research gate. net/publication/ $\underline{266219759}$

Polson, R.A and Spencer, D.S.C. 1991. The technology adoption process in subsistence agriculture: The case of cassava in South Western Nigeria. Agricultural System 36: 65-77. 